DOI 10.12737/article_5bcf57af5d83b6.20549781

УДК 631.372

\author{
ВЛИЯНИЕ УРОВНЯ ЭКСПЛУАТАЦИИ ТРАКТОРОВ \\ В СЕЛЬСКОХОЗЯЙСТВЕННОМ ПРОИЗВОДСТВЕ НА \\ ПОКАЗАТЕЛИ ИХ НАДЕЖНОСТИ \\ Галиев И.Г., Хусаинов Р.К., Хусаинова Т.А., Ситдиков Ф.Ф., \\ Пикмуллин Г.В., Булгариев Г.Г.
}

\begin{abstract}
Реферат. В процессе эксплуатации тракторов осуществляется их взаимодействие как объекта управления с динамическими нагрузками при выполнении технологических операций, природноклиматическими, эксплуатационными, организационными условиями, с одной стороны, и техническая эксплуатация - с другой, т.е. техника находится под влиянием условий функционирования. Комплексным, безразмерным показателем условий функционирования тракторов в аграрном производстве является уровень их эксплуатации. Уровень эксплуатации трактора - это состояние их эксплуатации в хозяйстве, который определяется степенью реализации мероприятий технической эксплуатации техники и процентом привлечения тракторов в трудоемкие процессы при их использовании по назначению. Теоретический уровень эксплуатации трактора может меняться от 0 до 1. При этом, 1 - соответствует состоянию эксплуатации трактора, при котором расход ресурса минимален, т.е. степень реализации обобщенных факторов технической эксплуатации соответствуют требованиям ГОСТ и трактор выполняет работы с наименьшим удельным сопротивлением; 0 - теоретический, соответствует состоянию эксплуатации трактора, при котором расход ресурса максимален, т.е. техническая эксплуатация трактора не выполняется и трактор выполняет работы с максимальным удельным сопротивлением. Нами определены уровни эксплуатации тракторов и показатели их надежности в хозяйствах РТ. В результате совместной математической обработки получены закономерности изменения этих показателей в зависимости от уровня эксплуатации тракторов.
\end{abstract}

Ключевые слова: уровень эксплуатации, условия функционирования, расход ресурса, годовая наработка, повышение эффективности.

Введение. Современный этап развития аграрного производства характеризуется как переходный период в рыночные отношения. В свою очередь рыночным отношениям свойственны кризисные ситуации, тем более в начале формирования структуры хозяйственной деятельности предприятий агропромышленного комплекса.

Давно назрел вопрос о возможных путях выхода из создавшегося положения. В ситуации, когда цены на новые трактора непомерно растут, количество техники в аграрном производстве снижается, решением назревшей проблемы является повышение эффективности их использования, что приведет к снижению себестоимости продукции сельского хозяйства и повысит ее конкурентоспособность [1].

Повышение эффективности эксплуатации тракторов непосредственно связано с оценкой их условий функционирования в хозяйствах АПК и разработкой мероприятий по его улучшению. Условия функционирования техники оцениваются комплексным безразмерным показателем - уровнем эксплуатации [2].

Состояние технической эксплуатации тракторов и процент привлечения трактора к различным видам сельскохозяйственных работ, которые в свою очередь характеризуются разными удельными сопротивлениями агрегатов, определяют величину расхода ресурса агрегатов и систем. Расход ресурса — это величина уменьшения остаточного ресурса при выполнении определенного объема работ [3, 4].

Уровень эксплуатации трактора может быть определена как в прошлом, для определения тенденции изменения расхода ресурсов систем и агрегатов трактора, так и на плановый период, для разработки мероприятий по повышению уровня обобщенных факторов технической эксплуатации тракторов и определения номенклатуры сельскохозяйственных работ на следующий период с учетом обоснования и определения оптимальных значений расхода ресурсов систем и агрегатов трактора.

Повышение эффективности эксплуатации тракторов в различных условиях их использования основаны на установлении закономерностей изменения показателей надежности тракторов от уровня эксплуатации с учетом состояния техники. В связи с этим ставится цель исследования: установление закономерностей влияния уровня эксплуатации трактоpa, т.е. состояния технической эксплуатации техники, с одной стороны, и динамических нагрузок при выполнении технологических операций на интенсивность расхода ресурсов агрегатов и систем тракторов - с другой, на показатели их надежности $[5,6,7]$.

Анализ и обсуждение результатов исследования.

Для достижения цели необходимо выполнить следующие исследовательские работы: 
- определение состояние агрегатов и систем каждого исследуемого трактора в определенных условиях функционирования;

- определение показателей надежности исследуемых тракторов при выполнении различных видов сельскохозяйственных работ.

Решение данных задач связаны с необходимостью выбора объектов наблюдения, т.е. агроклиматических, административных районов, хозяйств и марку трактора.

Для нахождения показателей надежности тракторов было проведено исследование в сельскохозяйственных предприятиях Республики Татарстан. При этом уровень эксплуатации находилась в пределах $0,5 \ldots 0,8$. В этих предприятиях был проведен полный анализ эффектности эксплуатации тракторов, который отражается в удельных затратах на устранение отказов двигателя до и после ремонта. Все эти показатели в большей степени зависят от уровня эксплуатации тракторов. Откуда видно, что по мере увеличения уровня эксплуатации показатели надежности увеличиваются. На основе этого, по каждому хозяйству были найдены средние удельные затраты на проведение текущих ремонтов тракторов МТ3 -80, МТ3 - 82.

Поскольку в период проведения экспериментальных исследований в исследуемой зоне $49,9 \%$ от всего машинно-тракторного парка составляют колесные трактора, и соответственно был выбран МТ3 - 80, МТ3 - 82.

Сбор информации в условиях эксплуатации для оценки показателей надежности тракторов осуществлялся в соответствии с ОСТ 70.2.8-82. Периодичность наблюдений - не реже 2 раз в месяц. На каждый наблюдаемый трактор заводился журнал наблюдений рекомендуемой формы $[8,9]$.

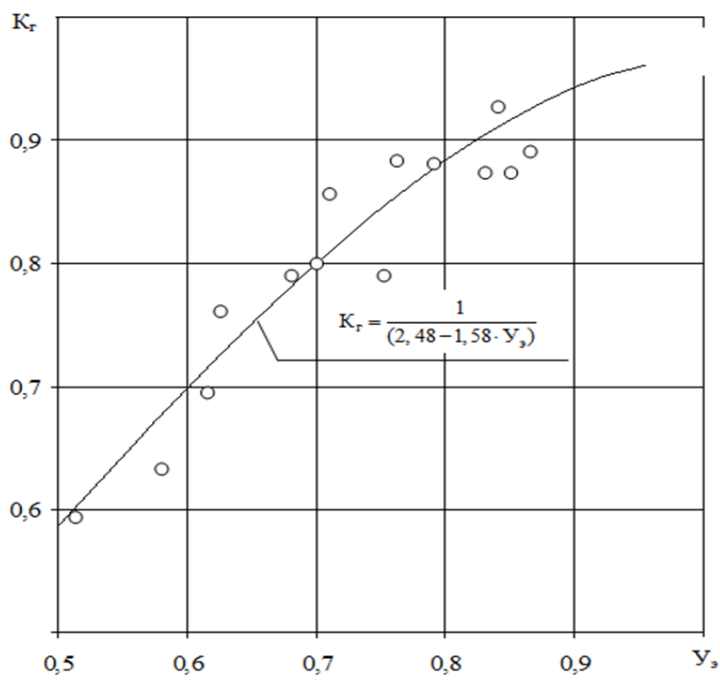

Рисунок 1 - Зависимость коэффициента готовности от уровня эксплуатации тракторов МТ3- 80, МТ3- 82

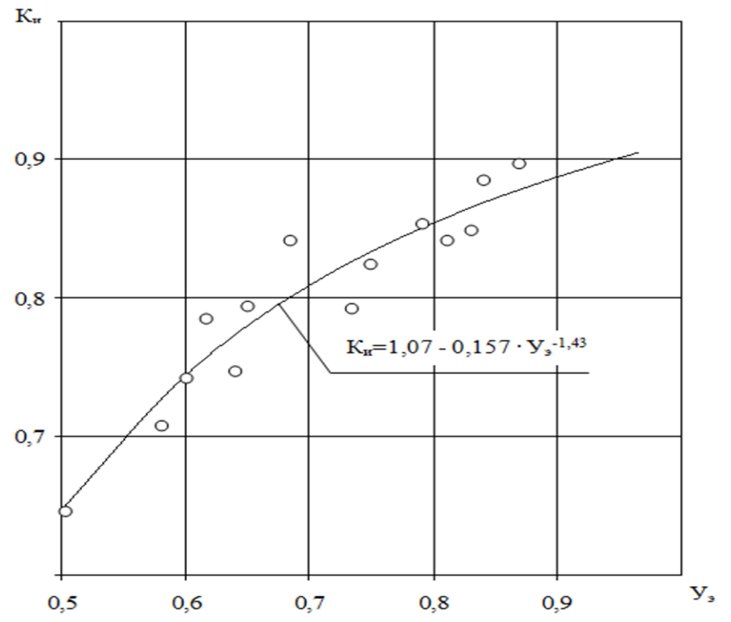

Рисунок 2 - Зависимость коэффициента использования от уровня эксплуатации тракторов МТ3 - 80, МТ3 - 82.

В наблюдательные листы вносилась информация об отказах: дата появления отказа, наработка трактора в моточасах от начала наблюдений до момента отказа, наименование отказавшего агрегата, краткая характеристика отказа и изменение эксплуатационных показателей каждого исследуемого трактора. При характеристике отказов были использованы рекомендации ОСТ 70.2.8-82 [10, 11].

Как показали результаты наблюдений, надежность трактора зависит от уровня эксплуатации. Далее были получены закономерности изменения показателей надежности, которые представлены в виде графиков.

Зависимость коэффициента готовности от уровня эксплуатации выражается формулой:

$$
\mathrm{K}_{\mathrm{r}}=\frac{1}{\left(2,48-1,58 \cdot \mathrm{y}_{\mathrm{g}}\right)}
$$

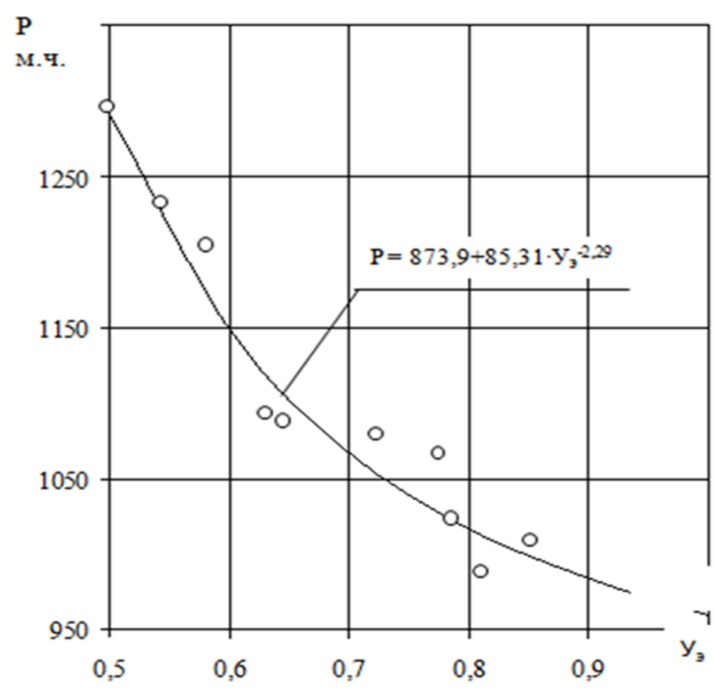

Рисунок 3 - Зависимость расхода ресурса двигателя от уровня эксплуатации тракторов МT3-80,МT3-82

Вестник Казанского ГАУ № 3(50) 2018 
при этом коэффициент корреляции $\mathrm{R}_{\Gamma}=$ $0,81, \mathrm{~m}_{\mathrm{R}}=0,23$;

Где $\mathrm{R}_{\text {г }}$ - коэффициент корреляции; $\mathrm{m}_{\mathrm{R}}$ ошибка коэффициента корреляции.

Зависимость коэффициента использования выглядит следующим образом:

$$
\mathrm{K}_{\mathrm{и}}=1,07-0,157 \cdot \mathrm{y}_{\ni}^{-1,43}
$$

при этом коэффициент корреляции: $\mathrm{R}_{\text {и }}=$ $0,72, \mathrm{~m}_{\mathrm{R}}=0,21$;

Расход ресурса трактора является важным показателем надежности, который зависит от уровня эксплуатации трактора.
Выводы. Исходя из исследований можно сделать следующие выводы, при увеличении уровня эксплуатации от 0,5 до 1,0 :

- коэффициента готовности повысится от 0,592 до 0,94, т.е. на $37 \%$.

- коэффициента использования увеличится от 0,58 до 0,92 , т.е. на $36,9 \%$.

- расход ресурса уменьшится на $36 \%$.

Исходя из графиков видно, что с увеличением уровня эксплуатации тракторов существует тенденция к увеличению показателей надежности тракторов, а расход ресурса двигателя уменьшается.

Литература

1. Галиев И.Г. Повышение эффективности использования тракторов с учетом условий их функционирования. - Казань: Изд-во Казан. ун-та, 2002.- 204 с.

2. Волков М.К. Исследование и совершенствование способов получения достоверной информации об отказах сельскохозяйственной техники: Автореф. дис. .... канд. техн. наук. - Челябинск, 1982. - 18 с.

3. Галиев И. Г., Хусаинов Р. К. Обоснование расхода ресурса агрегатов и систем трактора с учетом дифференцированного подхода при назначении технологических операций на плановый период // Вестник Казанского государственного аграрного университета. - 2013. - №2 (28). - С. 73-77

4. Галиев И.Г., Хусаинов Р.К. Определение весомости технологических операций и уровня расхода ресурса агрегатов и систем трактора//Вестник Казанского ГАУ. - 2012. - №3. - С. 90-96.

5. Галиев И.Г. Обоснование выбора критериев обеспечения надежности функционирования сельскохозяйственной техники/И.Г. Галлиев, С.М. Яхин, А.Р. Валиев, А.А. Мухаметшин, Р.К. Хусаинов//Материали за VIII международна научна практична конференция “Новини на научния прогресс -2012". -София «Бял Град -БГ» ООД, 2012. -96 с.

6. Галиев И.Г., Мухаметшин А.А., Хусаинов Р.К. Повышение эффективности использования тракторов в аграрном производстве. - Казань: Изд-во Казан-ский ГАУ, 2015.-152 с.

7. Хафизов Р.Н. Повышения эффективности использования тракторов / Р.Н. Хафизов, К.А. Хафизов // Механизация и электрификация сельского хозяйства. - 2010. - №12. - С. 14 - 15.

8. Бабаченко Л.А., Щукин А.Р. Оценка уровня эксплуатации тракторов // Механизация и электрификация сельского хозяйства. -1985. -№1. -С.24-26.

9. Галиев И.Г., Яхин С.М., Валиев А.Р., Мухаметшин А.А., Хусаинов Р.К. Обоснование дифференциации сельскохозяйственных работ по условию безотказности выполнения технологических операций // Мaterialy VIII Miedzynarodowej naukowi-praktycznej konferencji “Nauka.: teoria ipraktyka - 2012" Volume 9. Ekologia Rolnictwo. Weterynaria.: Przemysl.Nauka i studia - 80 str. (c. 23-26)

10. Иофинов С.А. Эксплуатация машинно-тракторного парка. - М.: Колос, 1974. - 470 с.

11. Обоснование уровня дифференциации сельскохозяйственных работ по тракторам Галиев И.Г., Зиганшин Б.Г., Абдрахманов Р.К., Хусаинов Р.К. // Техника и оборудование для села. - 2017. - № 10. - С. 28 31.

Сведения об авторах:

Галиев Ильгиз Гакифович - доктор технических наук, профессор кафедры эксплуатация и ремонта машин, e-mail: drgali@mail.ru

Хусаинов Раиль Камиевич - кандидат технических наук, доцент, e-mail: rail-1312@mail.ru

Хусаинова Татьяна Александровна - магистр

ФГБОУ ВО «Казанский государственный аграрный университет», г. Казань, Россия

Ситдиков Фарит Фоатович - кандидат технических наук, доцент, e-mail: fa-sit@mail.ru

Елабужский институт (филиал) ФГАОУ ВО «Казанский (Приволжский) федеральный университет», г. Елабуга, Россия.

Булгариев Гумар Галиаскарович - кандидат технических наук, e-mail: bulgariev1959@mail.ru

Пикмуллин Геннадий Васильевич - кандидат технических наук, e-mail: pikmullin@mail.ru

ФГБОУ ВО «Казанский государственный аграрный университет», г. Казань, Россия

\section{INFLUENCE OF THE TRACTORS' OPERATION LEVEL ON ITS RELIABILITY INDICATORS IN AGRICULTURAL PRODUCTION}

Galiev I.G., Khusainov R.K., Khusainova T.A., Sitdikov F.F., Pikmullin G.V., Bulgariev G.G.

Abstract. During the tractors' operation, they interact as a control object with dynamic loads during technological operations with climatic, operational, organizational conditions on the one hand, and technical operation on the other, i.e. machinery is influenced by operating conditions. A comprehensive, dimensionless indicator of the operating conditions of tractors in agricultural production is the level of their operation. The level of operation of the tractor is the state of their operation in the household, which is determined by the degree of implementation of technical maintenance activities of 
equipment and the percentage of attracting tractors in labor-intensive processes when used as intended. The theoretical level of operation of the tractor can vary from 0 to 1 . At the same time, 1 corresponds to the operating state of the tractor, at which the resource consumption is minimal, i.e. the degree of implementation of generalized factors of technical operation meet the State Standard requirements and the tractor performs work with the lowest specific resistance; 0 - theoretical, corresponds to the operating state of the tractor, at which the resource consumption is maximum, i.e. technical operation of the tractor is not performed and the tractor performs works with maximum resistivity. We have determined the levels of operation of tractors and indicators of their reliability in the farms of the Republic of Tatarstan. As a result of joint mathematical processing, regularities of changes in these indicators were obtained depending on the level of operation of tractors.

Key words: level of operation, operating conditions, resource consumption, annual operating time, efficiency increase.

\section{References}

1. Galiev I.G. Povyshenie effektivnosti ispolzovaniya traktorov s uchetom usloviy ikh funktsionirovaniya. [Improving the efficiency of the use of tractors, taking into account the conditions of their operation]. - Kazan: Izd-vo Kazan. un-ta, 2002.- P. 204.

2. Volkov M.K. Issledovanie i sovershenstvovanie sposobov polucheniya dostovernoy informatsii ob otkazakh selskokhozyaystvennoy tekhniki: Avtoref. dis. ... kand. tekhn. nauk. (Research and improvement of ways to obtain reliable information about the failures of agricultural machinery: Author's abstract of the thesis for a degree of P.h.D. of Technical sciences). - Chelyabinsk, 1982. - P. 18.

3. Galiev I. G., Khusainov R. K. Justification of the resource consumption of the aggregates and systems of the tractor, taking into account the differentiated approach in the designation of technological operations for the planned period. [Obosnovanie raskhoda resursa agregatov i sistem traktora s uchetom differentsirovannogo podkhoda pri naznachenii tekhnologicheskikh operatsiy na planovyy period]. // Vestnik Kazanskogo gosudarstvennogo agrarnogo universiteta. - The Herald of Kazan State Agrarian University. - 2013. - №2 (28). - P. 73-77.

4. Galiev I.G., Khusainov R.K. Determination of the weight of technological operations and the level of resource consumption of the units and systems of the tractor. [Opredelenie vesomosti tekhnologicheskikh operatsiy i urovnya raskhoda resursa agregatov i sistem traktora]. // Vestnik Kazanskogo gosudarstvennogo agrarnogo universiteta. - The Herald of Kazan State Agrarian University. - 2012. - №3. - P. 90-96.

5. Galiev I.G. Obosnovanie vybora kriteriev obespecheniya nadezhnosti funktsionirovaniya selskokhozyaystvennoy tekhniki. [Justification of the choice of criteria for ensuring the reliability of the functioning of agricultural machinery]. I.G. Galliev, S.M. Yakhin, A.R. Valiev, A.A. Mukhametshin, R.K. Khusainov// Материали за VIII международна научна практична конференция "Новини на научния прогресс -2012". - Sofiya "Byal Grad -BG” OOD, 2012. - P. 96.

6. Galiev I.G., Mukhametshin A.A., Khusainov R.K. Povyshenie effektivnosti ispolzovaniya traktorov v agrarnom proizvodstve. [Improving the efficiency of the use of tractors in agricultural production]. - Kazan: Izd-vo Kazan-skiy GAU, 2015. - P. 152.

7. Khafizov R.N. Improving the efficiency of the use of tractors. [Povysheniya effektivnosti ispolzovaniya traktorov]. / R.N. Khafizov, K.A. Khafizov // Mekhanizatsiya i elektrifikatsiya selskogo khozyaystva. - Mechanization and electrification of agriculture. - 2010. - №12. - P. $14-15$.

8. Babachenko L.A., Shchukin A.R. Assessment of the level of operation of tractors. [Otsenka urovnya ekspluatatsii traktorov]. // Mekhanizatsiya i elektrifikatsiya selskogo khozyaystva. - Mechanization and electrification of agriculture. 1985. -№1. - P. 24-26.

9. Galiev I.G., Yakhin S.M., Valiev A.R., Mukhametshin A.A., Khusainov R.K. Obosnovanie differentsiatsii selskokhozyaystvennykh rabot po usloviyu bezotkaznosti vypolneniya tekhnologicheskikh operatsiy. (Justification of the differentiation of agricultural work on the condition of reliability of technological operations). // Materialy VIII Miedzynarodowej naukowi-praktycznej konferencji "Nauka.: teoria ipraktyka - 2012" Volume 9. Ekologia Rolnictwo. Weterynaria.: Przemysl.Nauka i studia -80 str -80 str. (P. 23-26)

10. Iofinov S.A. Ekspluatatsiya mashinno-traktornogo parka. [Operation of the machine and tractor park]. - M.: Kolos, 1974. - P. 470

11. Justification of the level of differentiation of agricultural work on tractors. [Obosnovanie urovnya differentsiatsii selskokhozyaystvennykh rabot po traktoram]. // Galiev I.G., Ziganshin B.G., Abdrakhmanov R.K., Khusainov R.K. // Tekhnika i oborudovaniye dlya sela. - Equipment and equipment for the village. - 2017. - №10. - P. 28-31.

\section{Authors:}

Galiev Ilgiz Gakifovich - Doctor of Technical Sciences, Professor of Machine maintenance and repair Department, e-mail: drgali@mail.ru

Khusainov Rail Kamlievich - Ph.D. of Technical Sciences, Associate Professor, e-mail: rail-1312@mail.ru

Khusainova Tatyana Aleksandrovna - Master

Kazan State Agrarian University, Kazan, Russia

Sitdikov Farit Foatovich - Ph.D. of Technical Sciences, Associate Professor, e-mail: fa-sit@mail.ru

Elabuga Institute (branch) of Kazan (Volga) Federal University, Elabuga, Russia.

Bulgariev Gumar Galiaskarovich - Ph.D. of Technical Sciences, e-mail: bulgariev1959@mail.ru

Pikmullin Gennadiy Vasilevich - Ph.D. of Technical Sciences, e-mail: pikmullin@mail.ru

Kazan State Agrarian University, Kazan, Russia 